This item was submitted to Loughborough's Research Repository by the author.

Items in Figshare are protected by copyright, with all rights reserved, unless otherwise indicated.

\title{
The GENIE workshop and their contribution to curricula for inclusive design
}

PLEASE CITE THE PUBLISHED VERSION

http://dx.doi.org/10.4017/gt.2004.03.01.006.00

\section{PUBLISHER}

(c) International Society for Gerontechnology

LICENCE

CC BY-NC-ND 4.0

\section{REPOSITORY RECORD}

Dekker, Marijke C., C.A. Nicolle, and Johan F.M. Molenbroek. 2019. "The GENIE Workshop and Their Contribution to Curricula for Inclusive Design". figshare. https://hdl.handle.net/2134/2186. 
This item was submitted to Loughborough's Institutional Repository (https://dspace.lboro.ac.uk/) by the author and is made available under the following Creative Commons Licence conditions.

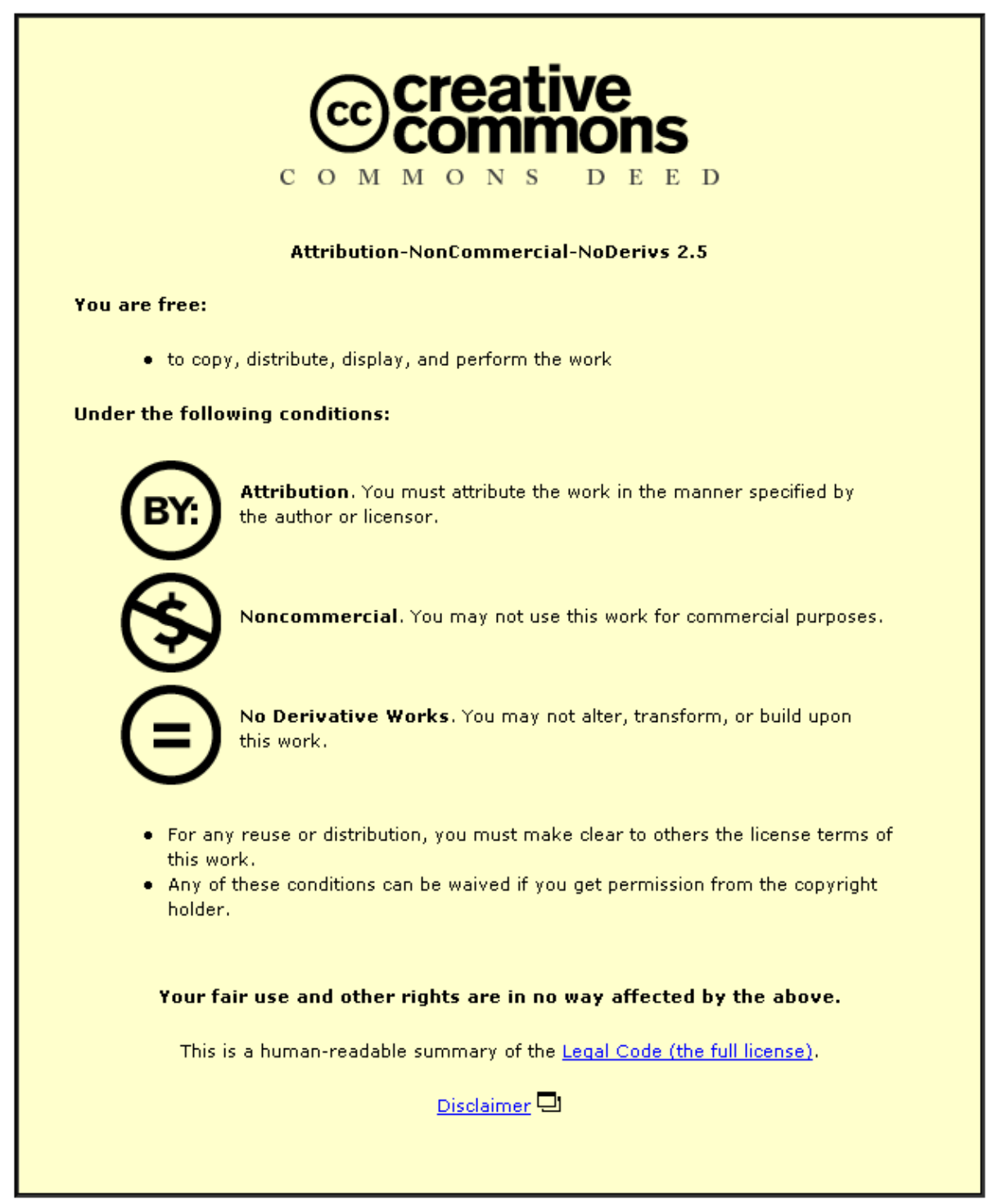

For the full text of this licence, please go to: http://creativecommons.org/licenses/by-nc-nd/2.5/ 


\title{
GENIE workshops for curricula with user involvement and inclusive design
}

\author{
Marijke C. Dekker MSc
}

Faculty of Industrial Design, Delft University of Technology

Landbergstraat 15, 2628 CE Delft, NL. e-mail: m.c.dekker@io.tudelft.nl

Colette Nicolle MSc

Ergonomics and Safety Research Institute, Loughborough University

Loughborough, Leicestershire, LE11 3UZ, UK. e-mail: c.a.nicolle@lboro.ac.uk

Johan F.M. Molenbroek PhD MSc

Faculty of Industrial Design, Delft University of Technology

Landbergstraat 15, 2628 CE Delft, NL. e-mail: j.f.m.molenbroek@io.tudelft.nl

M.C. Dekker, C. Nicolle, J.F.M. Molenbroek. GENIE workshops for curricula with user involvement and inclusive design. Gerontechnology 2004; 3(1): 35-42. The GENIE (Gerontechnology Education Network In Europe) Thematic Network project was established to improve the quality of education in gerontechnology and to promote its acceptance across institutions of higher learning. A key component of the final GENIE meeting in Helsinki, August 2001, consisted of a number of Workshops spanning different age groups and disciplines. The purpose of these workshops was to provide an experimental and learning opportunity, enabling students to work together with older people to identify potential design solutions. The final outcome of the workshops was in the form of an idea for a new product, technology, service, system, or environment. Since the focus of the methodology used was to involve the user group of older persons in all stages of the design process: (i) obtaining information on a specific topic in relation to the users, (ii) identifying users' requirements, (iii) translating them into realistic designs, (iv) discussing their utility and usability with the seniors, (v) refining the designs, and (vi) later assessing whether the needs are being met, these outcomes matched to the requirements of the seniors and resulted in valuable solutions for this user group. As an example of the methodology, the mobility theme will be treated. The paper will conclude with suggestions emerging from the workshop which can contribute to key knowledge and skills for curricula in inclusive design.

Keywords: education, workshop, user involvement, design for all, inclusive design 
The GENIE (Gerontechnology Education Network In Europe) Thematic Network project $^{1}$ was funded by the SOCRATES/ERASMUS Programme of the European Union and ran from 1998 to 2001. GENIE was established to improve awareness that the developments in technology offer an opportunity to increase the participation, integration, and independence of all citizens, including people who are older. The GENIE network had 42 partner institutes for higher learning originating from $14 \mathrm{EU}$ countries and 4 new associated countries. GENIE assisted in the enhancement of the European dimension of curriculum and teaching staff development, as well as student mobility schemes. The network has facilitated introducing gerontechnology into higher education of different disciplines by the creation and exchange of up-to-date information via meetings, conferences, workshops, syllabi and materials, a design competition, presentations of good practice, guestlectureships, internet and list server communication, and e-learning.

The aims of GENIE can be summarised as:

(i) Promoting the acceptance of gerontechnology as part of regular higher education;

(ii) Improving the quality of gerontechnology education;

(iii) Enabling GENIE-network partners to work together to improve awareness and to create exchange of up-to-date information;

(iv) Promoting the growth of geronrelated knowledge.

The project has resulted in a number of outputs $^{1}$; the main ones will be highlighted here. A digital 'Learning Map' (Figure 1) was created to give access to knowledge about various areas related to gerontechnology and to be used by all people interested in the topic of ageing, including students, tutors, and professionals. Every area has an 'introduction' to the topic, and by clicking further more detailed www-links, documents and publications can be found. Another outcome of the project was the Case Studies Library (Figure 2). The case studies, presented by visuals and text, are examples of services, products, and research projects that have considered the issues of gerontechnology. They are grouped under broad headings such as Travel/Leisure/Mobility or Living \& Working. Within each of these a variety of student and professional work can be viewed.

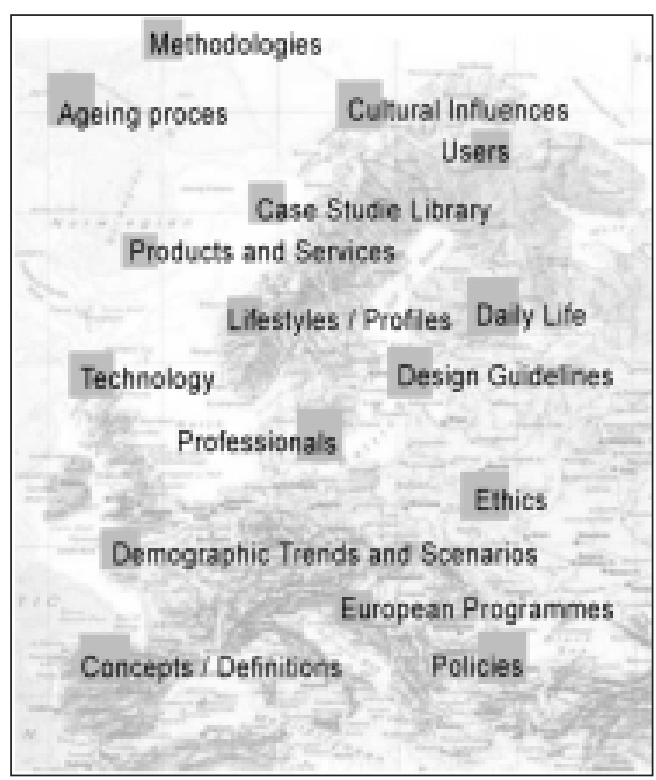

Figure 1: The Learning Map

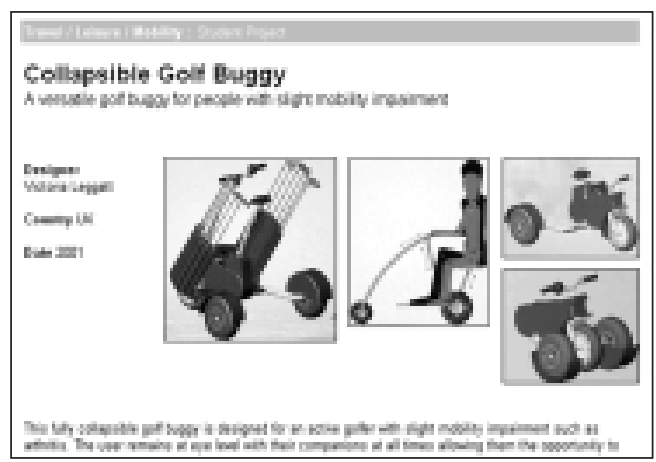

Figure 2: Example of a case study 
A third outcome of GENIE was the inclusion of a gerontechnology related project in the RSA Student Design Awards, a design competition since 1924, to bring together industry and education and to encourage young designers throughout the UK and beyond. The principal aim of this project, supported by GENIE and the UK's Design Council, is to encourage multidisciplinary teams (social sciences, ergonomics, engineering, medicine, nursing, and physiotherapy) to work together in the area of gerontechnology (defined as an age inclusive society supported by technology). The RSA Student Design Awards are very recently renamed to RSA Design Directions, and the 'inclusive' category can now be found on the web². A final outcome of GENIE was the creation of the book 'Gerontechnology Why and How' 3 to which several members of the GENIE network contributed.

The three-year GENIE project was completed by a final meeting, taking place at the University of Arts and Design (UIAH) in Helsinki in August 2001, and consisted of two integrated parts. Firstly, a number of seminars and lectures were held with key guest speakers and secondly, a number of Workshops took place over a 2-day period, spanning different age groups and

Table 1: SWOT analysis of people over 50

\begin{tabular}{|c|c|}
\hline $\begin{array}{l}\text { Strengths } \\
\text { - } \text { Experience } \\
\text { - Perspective } \\
\text { - } \text { Confidence } \\
\text { - Some seniority } \\
\text { - Financially secure (?) } \\
\text { - Self aware } \\
\text { - Realistic } \\
\text { - Knowledge of psychology } \\
\text { - Knowledge } \\
\text { - Networks } \\
\text { - Tolerance } \\
\text { - } \text { Memories } \\
\text { - Relaxe of fulfilment } \\
\text { - Big consumer market } \\
\text { - More and more per population }\end{array}$ & $\begin{array}{l}\text { Weaknesses } \\
\text { - Less tolerant } \\
\text { - Loss of memory } \\
\text { - Afraid of change } \\
\text { - Disengagement } \\
\text { - Less stamina } \\
\text { - Arrogance } \\
\text { - Less independent } \\
\text { - Dertfall of new knowledge } \\
\text { - } \text { reaction-time, mobility } \\
\text { - Longer recuperation } \\
\text { - Songer learning / adapting } \\
\text { - Onset of chronic illnesses } \\
\text { - Being 'boring' } \\
\text { - Losing face } \\
\text { - Not be } 20 \text { again } \\
\text { - Worn pathways 'experiences' }\end{array}$ \\
\hline $\begin{array}{l}\text { Opportunities } \\
\text { - More time } \\
\text { - } \text { Cow activities, non-paid involvement } \\
\text { - Grandparenthood } \\
\text { - Respect } \\
\text { - Full-time employment } \\
\text { - } \text { Freedom } \\
\text { - Communication with other people } \\
\text { - Change context } \\
\text { - Enhance communication } \\
\text { - Mastery of .... } \\
\text { - Increased sociability } \\
\text { - Passing information (cascade) } \\
\text { - Creond "career" } \\
\text { - } \text { Accese more "care" workibility/designs } \\
\text { - Longevity with health } \\
\text { - Better and easier interfaces } \\
\text { - Larger market }\end{array}$ & $\begin{array}{l}\text { Threats } \\
\text { - Isolation - social, physical, professional } \\
\text { - Abandonment } \\
\text { - Death } \\
\text { - } \text { Being a 'burden' for family - financial, emotional } \\
\text { - Frailty threats } \\
\text { - Unfriendly physical environment } \\
\text { - Stigmatisation of seniors } \\
\text { - Losing your developed lifestyle } \\
\text { - Alienation } \\
\text { - Dependence on medical regimes } \\
\text { - Wepressions }\end{array}$ \\
\hline
\end{tabular}


disciplines. The purpose of these workshops was to provide an experimental and learning opportunity, which would bring students together with older people to identify potential design solutions in the form of a new product, technology, service, system, or environment matched to the requirements of the older person. It is these workshops that form the basis of this paper-workshops that have promoted a better understanding of inclusive design principles ${ }^{4}$ and the importance of user involvement in all stages of the design process.

\section{GENERAL METHODOLOGY}

The first stage of the workshops involved a SWOT analysis5-7 facilitated by Prof. Norman McNally of Glasgow School of Art. This analysis was conducted as a brainstorming exercise to identify the Strengths, Weaknesses, Opportunities, and Threats in everyday living for people over 50 years of age (Table 1 ).

Five separate groups were then formed (Mobility, Work, Technology, Housing, and Communication), each group consisting of 3 students from a range of different countries and disciplines, 1 senior person, 1 facilitator, and 1 tutor. The seniors could be consulted by the different groups throughout the entire activity, giving their view on their own personal needs, problems, and wishes.

The five facilitators started with an introduction to their individual groups to outline their subject briefly. The 'Learning map' of the GENIE web site was used as a starting point for finding specific relevant information about the topic. During this time the seniors were consulted to identify their requirements and to generate ideas for a new product, technology, service, or environment that could optimise the opportunities and reduce the threats with regard to their mobility, work, technology, housing, and communication. The team then together discussed possible solutions, illustrated alternatives, selected final ideas, and prepared a presentation for a plenary session.

\section{METHODOLOGY AND RESULTS OF THE MOBILITY GROUP}

The Mobility workshop will now be described in more detail, in particular describing the specific methods used to identify the older person's needs, problems, and wishes and the sort of solutions that were suggested. In addition to the students, facilitator, tutor and older person, the participants of the workshop included two other seniors who 'floated' among the different groups.

\section{Step 1 - Setting the scene}

Some background information from the GENIE Web site was first provided to the participants: 'For people who are older or disabled, maintaining mobility means more independence and a better quality of life. Being able to travel by car or public transport enables a person to take part in work or leisure activities outside the home, without a reliance on others to do so. However, transport vehicles, systems, and services are not always designed with their needs and abilities taken into account and so older and disabled people are often less likely to travel than other citizens. This may be because the transport is not fully accessible, or it may be because the traveller does not know that it is accessible. And so, in order for a person to feel confident to begin a journey, no matter what the distance, it is important that the traveller can obtain all the required information before and during a journey (e.g., timetables, whether there are any stairs between train platforms, etc.)'.

A second, more compact, SWOT analysis (covering only opportunities and threats) was then conducted on the specific topic of Mobility (Table 2). Mobility was defined as applying to a number of areas, including not only personal mobility, but 
Table 2: SWOT analysis for Mobility topic

\begin{tabular}{|c|c|}
\hline $\begin{array}{l}\text { Opportunities } \\
\text { - Relaxing journey (activity / 'day out') } \\
\text { - Socialising } \\
\text { - Independence } \\
\text { - Confidence (information possibly provided } \\
\text { through technology) } \\
\text { - Visiting family } \\
\text { - New social role (helping others) }\end{array}$ & $\begin{array}{l}\text { Threats } \\
\text { - Timing } \\
\text { - To get off, moving vehicle } \\
\text { - Feeling insecure } \\
\text { - } \text { Familiar versus unfamiliar journeys } \\
\text { - Luggage } \\
\text { - Differences between countries } \\
\text { - Physical (dis)ability to get to station/stop } \\
\text { - Lack of available service/seating } \\
\text { - Lack of 'human' help, introduction of technology } \\
\text { - Complexity (especially when making a journey } \\
\text { using different modes of transport) }\end{array}$ \\
\hline $\begin{array}{l}\text { Specific to Technologies } \\
\text { - Security (e.g. informing emergency services) } \\
\text { - Testing parameters (consistency, nationally } \\
\text { and internationally) }\end{array}$ & $\begin{array}{l}\text { Specific to Technologies } \\
\text { - Locating the system or information services } \\
\text { - Understanding the system } \\
\text { - Confirmation of decision } \\
\text { - Safety (in obscure areas) } \\
\text { - Physical accessibility (e.g. using information } \\
\text { kiosks) } \\
\text { - Decision and action times (timeout and } \\
\text { - Rroviding pin numbers quickly) } \\
\text { Regulations \& standards (variance from } \\
\text { country to country) }\end{array}$ \\
\hline
\end{tabular}

also private and public transport in both city and rural environments, using buses, trams, underground, and trains. When discussing the outcomes with the group, it was evident that a substantial number of opportunities and especially threats related more specifically to the use of technologies while travelling by public or private transportation. Therefore these were grouped separately in Table 2, although there is a fair degree of overlap with the general aspects in each category. While discussing the underlying reasons for labelling these aspects as being technology-related threats or opportunities, occasions were found to optimise the opportunities, reduce the threats or moreover to turn the threats into opportunities. After consulting the other older persons, it was decided to concentrate on public city transport, and more specifically on buses, as this is where difficulties most frequently arose.

\section{Step 2 - User Requirements}

There was then a discussion in the group about what methods or tools could be used for identifying users' preferences, requirements, and problems, through interviews, either individual or group discussions, observation, etc. In order to gain a better understanding of the tasks involved and the requirements of the older traveller, the facilitator suggested performing a simplified Task Analysis, using Personalised Task Representation (PTR) $)^{8,9}$, in order to record the sequence of steps undertaken before, during, and after a bus journey. Through this human factors method, it was expected that solutions could more easily be focussed on key problem areas and requirements. The task

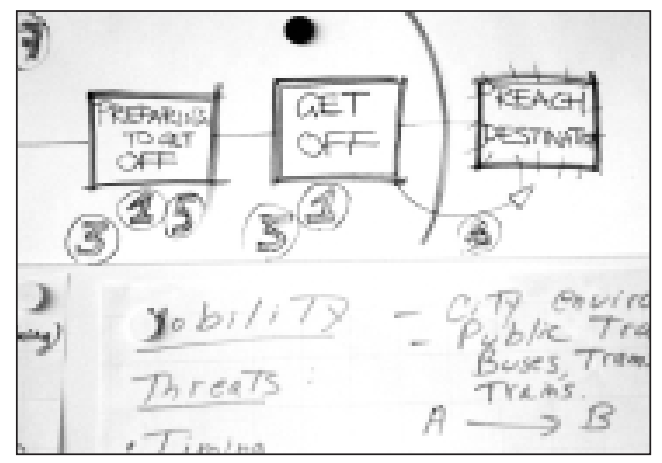

Figure 3: Fragment of the story board of the Mobility group 
analysis for taking a bus journey (Figure 3) identified the following tasks: get bus information, go to bus stop, wait for the bus, bus arrives, information to driver, get on bus, buy ticket, find your place, journey information / information of location, prepare to get off, get off, reach destination.

\section{Step 3 - Development and Iterative Evaluation}

The older person in the group pointed out a number of difficulties whilst travelling on the bus, referring to the threats in Table 2 and the tasks identified in the task analysis. It was suggested that human help was the preferred solution during many tasks. In some tasks, technology could support, but should not be seen to eliminate human assistance. Furthermore, under certain conditions, technology could deliver complete assistance without any human help. With this in mind the creation of ideas began. An interesting suggestion made by one of the students, and endorsed by the older person, was to have an additional, self-employed person on the bus, possibly someone called a 'Cacahouète (peanut) helper', who would be selling his or her products and at the same time providing assistance in a number of ways, from selling tickets to helping an older person to get off the bus. This idea was discussed with the seniors in order to evaluate its utility and usability, and it was agreed that this idea had the potential to not only give the older person more confidence to travel, but could also be less expensive to implement than other solutions. A more technology-based idea was an interactive route information board in the bus, which would locate the traveller's position and provide guidance on where to get off the bus. A further solution in which technology could support human assistance was the idea of obtaining travel information via human speech with the mobile phone. The pros and cons of these ideas were investigated and considered in the evaluation for the final presentation.

\section{Step 4 - Feedback}

These results, as well as those from the other workshops, were then presented by the students, to the Plenary Session. The vivid discussion (the audience responding on the thoughts and ideas) at the end of the presentations was a main outcome of the workshops.

\section{ConCLUSION}

The Workshops have awakened or refreshed the participants' awareness that user involvement is an important way to promote the inclusive design process and can stimulate the process of creating innovative ideas. But how can these ideas be promulgated to other students and teachers of design, ergonomics, engineering, computer studies, social sciences, medicine, nursing and physiotherapy, etc.? One of the authors has successfully used a shortened version of the GENIE workshop methodology in a 3hour lecture slot as part of the module Ergonomics of Disability and Ageing at Loughborough University. A multidisciplinary team of students from the Departments of Human Sciences and Design and Technology work together, the process being facilitated by lecturers in both ergonomics and design. Ideally an older or disabled person should participate, but role-play by one student in each group is a possible alternative. Not only does this provide an opportunity to empathise with the needs of older and disabled people, but it also gives the other students in the group an opportunity to practise user requirements, methods, and techniques in a supported situation. At Industrial Design of Delft University of Technology, the home base of two of the other authors, 'Design for All' and user involvement in design are integrated in the educational programme with lectures and practical exercises. Design for All is a main 
topic in the research programme. Bit by bit, the characteristics of the 'less known' users are investigated, documented, and made available, via accessible design tools, to future practitioners. Another topic in research and education is 'Usage Evaluation' with an emphasis on observational studies in context to learn more about the perceptions, cognitions, and actions of the current and future users $^{10}$.

\section{Ways forward}

It is also interesting to see that various initiatives are now working towards curricula in inclusive design. For example the IDCnet thematic network project, funded by the EU IST Programme, is focussing on core knowledge sets and skills that should be part of an inclusive design curriculum for information and communication products, systems and services $^{11}$. As a thematic network, a major aim of the project is also to support the creation of a European network to promote these interests, following the eEurope objectives ${ }^{12}$ and to coordinate its efforts with the European Design for All eAccessibility Network ${ }^{13}$ and the Design4All project ${ }^{14}$.

The methods and techniques piloted here could contribute to the key knowledge and skills which can form part of curricula in inclusive design. Such key knowledge and skills can include, for example:

(i) Knowledge as presented on the GENIE web site, including the digital 'Learning Map' and case studies which illustrate good design practice;

(ii) An understanding of human factors methods and tools which can be used to identify users' requirements and later assess whether those needs are being met; (iii) The acquisition of interpersonal skills for teamwork to enable students to work as 'agents of change' and convince the unwilling / disbelieving / unaware of the benefits of inclusive design ${ }^{15}$; (iv) The skills for translating user requirements into realistic designs, including aesthetic, functional and technical specifications (or having the knowledge of and experience working with other disciplines to accomplish this task);

(v) An understanding of the general principles of inclusive design, and more importantly, knowing how to put those principles into practice.

\section{Acknowledgement}

The authors would like to thank the GENIE network and the SOCRATES / ERASMUS Programme of the European Union for their support during the three year GENIE project. In relation to this article we would like to thank all participants and guest speakers to the final meeting and its workshops in Helsinki and in particular we would like to thank Prof. Norman McNally of Glasgow School of Art for demonstrating to us in a very stimulating way how a SWOT analysis can be the driving force for developing creative ideas. And of course, our thanks and commendation are due to the participants of the Mobility Workshop including Ulla Son, Herman Bouma, Etienne Lebreton, Vesa Kemppainen, and Tamsin Smith, for their hard work and enthusiasm during these workshop activities.

\section{References}

1. www.gerontechnology.info/genie

2. www.rsa-design.net/directions/ collaborations/inclusiveworlds

3. Harrington $\mathrm{TL}$, Harrington $\mathrm{MK}$, editors. Gerontechnology Why and How. Maastricht: Shaker; 2000

4. Clarkson J, Coleman R, Keates S, Lebbon C, editors. Inclusive Design Design for the whole population. London: Springer; 2003

5. Baxter M. Product Design - Practical methods for the systematic development of new products. London: Chapman and Hall; 1995 


\section{Student Paper}

6. deBono E. Six Thinking Hats. London: Pelican; 1987

7. Moody P. Decision Making - proven methods for better decisions. New York: McGraw-Hill; 1983

8. Gregory R. Personalised Task Representation. AMTE(E) Report TM79103, Copyright Controller HMSO; 1979

9. Poulson D, Ashby M, Richardson SJ, editors. USERfit. A practical handbook on user centred design for assistive technology. Brussels: ECSC-EC-EAEC; 1996; www.stakes.fi/include1-7-2.htm

10. www.io.tudelft.nl/research/ergonomics/ AED

11. www.idenet.info
12. www.europa.eu.int/information_society/ eeurope/index_en.htm

13. www.e-accessibility.org

14. www.d4all.gr

15. Nicolle C, Darzentas J. What to teach? A taxonomy of Knowledge and Skills for 'Design for All' Curricula related to $\mathrm{HCl}$. Presented at Including Accessibility and Inclusive Design in the Curriculum for Human Computer Interaction. Joint Workshop of IFIP WG 13.1 on Education in $\mathrm{HCl}$ and $\mathrm{HCl}$ Curriculum and IFIP WG 13.3 on $\mathrm{HCl}$ and Disability. INTERACT 2003, the IFIP TC13 International Human-Computer Interaction Conference, Zurich, Switzerland, 1-5 September 2003 